\title{
Lifecourse patterns of protein consumption and physical capability in later life
}

\author{
C. A. Munro ${ }^{1,2,3}$, A. J. Adamson ${ }^{1}$, A. M. Stephen ${ }^{4}$, D. Kuh ${ }^{5}$ and R. Cooper ${ }^{5}$ on behalf of the \\ NSHD Scientific and data collection Teams and John C. Mathers ${ }^{1,2,3}$ \\ ${ }^{1}$ Human Nutrition Research Centre, ${ }^{2}$ Institute for Ageing and Health, ${ }^{3}$ Centre for Brain Ageing and Vitality, Newcastle \\ University, Newcastle upon Tyne, NE4 5PL, ${ }^{4}$ MRC Human Nutrition Research, Cambridge CB1 9NL and ${ }^{5}$ MRC Unit for \\ Lifelong Health \& Ageing, London, WC1B 5JU, UK
}

Sarcopenia, the age-related loss of skeletal muscle mass and function, is associated with increased risk of disability, loss of independence and mortality. Protein consumption stimulates muscle protein synthesis and is associated with lean mass change in older adults ${ }^{(1)}$ and the anabolic response to feeding is attenuated in older people $\mathrm{e}^{(2,3)}$. We hypothesised that patterns of protein consumption across the lifecourse influence muscle protein synthesis and, ultimately, physical capability. This study aimed to test the hypothesis that low protein consumption throughout adulthood impairs physical capability in later life.

Participants in the MRC National Survey of Health and Development (The 1946 British birth cohort) provided dietary data (3 day food diaries) at three time points, when aged 36, 43 and $53 \mathrm{y}$. Clinic-based physical performance (hand grip strength, chair rise, timed up and go and standing balance) was measured in 2006/10 when participants were 60-64 y. Using data for those participants with dietary information in at least one survey $(n=3019)$, relationships between lifelong patterns of protein consumption and measures of physical performance and strength were investigated using the General Linear Model/ univariate analysis. Models were adjusted for gender, current height and weight, adult habitual physical activity, educational attainment, father's social class, smoking status, pulse- and mean arterial blood pressure.

\begin{tabular}{|c|c|c|c|c|}
\hline Protein intake group & $\begin{array}{l}\text { Mean protein intake } \\
(\mathrm{g} / \mathrm{d}) \text { All }(n)\end{array}$ & $\begin{array}{l}\text { Mean protein intake } \\
(\mathrm{g} / \mathrm{d}) \text { Females }(n)\end{array}$ & $\begin{array}{l}\text { Mean protein intake } \\
(\mathrm{g} / \mathrm{d}) \text { Males }(n)\end{array}$ & $\begin{array}{c}\text { Mean hand grip strength } \\
(\mathrm{kg})(95 \% \mathrm{CI})\end{array}$ \\
\hline Lowest quintile & $47.4(n=604)$ & $43.5(n=303)$ & $55.3(n=302)$ & $32.43(31.28-33.62)$ \\
\hline Other 4 quintiles & $79.0(n=2415)$ & $69.0(n=1209)$ & $87.8(n=1205)$ & $33.85(33.35-34.36)$ \\
\hline
\end{tabular}

Mean protein consumption $(\mathrm{g} / \mathrm{d})$ was associated with hand grip strength at 60-64 y. Compared with those in the higher quintiles of consumption, those in the lowest gender-specific quintile of protein consumption had significantly $(p=0.032)$ lower hand grip strength in later life. Relatively low protein consumption across 17 years of adult life was associated with a $4.3 \%$ lower hand grip strength at age $60-64$ y. Grip strength is a strong predictor of health and longevity ${ }^{(4)}$ so these data suggest that ensuring adequate protein intake through adulthood is important in ensuring healthy ageing.

1. Houston DK, Nicklas BJ, Ding J et al. (2008) AJCN 87, 150-155.

2. Katsanos CS, Kobayashi H, Sheffield-Moore M et al. (2005) AJCN 82, 1065-73.

3. Cuthbertson D, Smith K, Babraj J et al. (2005) FASEBJ 19, 422-4.

4. Cooper R, Kuh D, Hardy R ( 2010) Mortality Review Group: FALCon and HALCyon Study Teams. BMJ 341;c4467. 